\title{
Notas sobre culinária caipira na obra de Almeida Júnior
}

\section{Notes on caipira cuisine from Almeida Júnior's paintings}

Bruno Brito ${ }^{1}$

Muitos escritos sobre culinária caipira mencionam uma pequena pintura de 1895 intitulada Cozinha Caipira, do pintor ituano Almeida Júnior, artista responsável por retratar cenas rurais paulistas no último quartel do século XIX. De fato, a detalhada pintura nos fornece uma série de elementos significativos para compreender tal cultura alimentar, principalmente na forma de objetos como o pilão, a banqueta, a urupema, o fumeiro, o forno romano, o fogão de poial ou "de rabo", bem como a própria arquitetura em taipa de mão. No entanto, o restante das obras da fase regionalista, realizadas após seu regresso de Paris, nos dão muitas pistas para compreender de que modo estas populações se relacionavam com o meio rural, com os processos vitais e a própria alimentação. Além de Cozinha Caipira, neste trabalho irei comentar as seguintes pinturas: Apertando o Lombilho, Paisagem do Sítio Rio das Pedras, Caipiras Negaceando, Caipira Picando Fumo e O Violeiro.

Em Apertando o Lombilho temos um mastro no centro do terreiro. Vale ressaltar que este mastro não leva uma bandeira de santo no topo e por isso remete aos antigos mastros pagãos do hemisfério norte. É possível notar que há frutas espetadas no esteio, aliás, ainda hoje em algumas localidades do Vale do Paraíba, moradores da zona rural amarram espigas de milho e colocam ovos em sua base, fazendo do objeto um instrumento de fertilização agrícola, já que, simbolicamente liga o céu e a terra nos solstícios de inverno.

Já em Paisagem do Sítio Rio das Pedras adentramos o perímetro florestal não muito distante da casa roceira. Nesta pintura temos no primeiro plano uma espécie de palmito, comum principalmente nos sítios caiçaras do litoral. O pequeno ribeirão ao centro parece operar como uma subdivisão na propriedade, sendo a margem esquerda mais próxima da casa, justamente pelo fato da presença da palmeira e também pela cobertura rala do solo, provavelmente desgastada pelo pisoteamento humano e animal. Em contraposição, na margem direita temos uma árvore de grande porte ao fundo, que evoca a ideia de "mata virgem", intocada. Mais atrás há uma espécie de pinguela que conecta a margem civilizada à margem primitiva. Podemos empregar os termos de Lévi-Strauss a essa pintura: "o cru e o cozido", sendo a pequena ponte a representação da passagem do estado natural para o cultural. A mesma relação ocorre em Cozinha Caipira, como bem observou Daniela Perutti ao chamar atenção para a galinha na soleira da porta: a ave se encontra justamente no limite entre a natureza e a civilização, basta adentrar o recinto para ir direto para a panela e se tornar comida, ou seja, um elemento da cultura.

Por meio de uma narrativa espaço-temporal é possível conectar todas as pinturas citadas anteriormente empregando outros exemplos similares que dizem respeito à ocupação da paisagem e à alimentação. $O$ trabalho tem como objetivo ampliar o debate da cultura caipira e sua culinária a partir da obra de Almeida Júnior. 
Palavras-chave: Almeida Júnior; propriedade rural; culinária caipira; arte; antropologia. Keywords: Almeida Júnior; rural property; caipira cuisine; art; Anthropology.

1 Doutorando em Artes Visuais no Instituto de Artes da Universidade Estadual Paulista. 